\title{
Occurrence and risk assessment of phenolic endocrine disrupting chemicals in shallow groundwater resource from selected Nigerian rural settlements
}

\author{
Onyekachi ONYEKWERE, ${ }^{1}$ Chioma Joy OKONKWO*, ${ }^{2}$ Azubuike Bright OKOROAFOR, ${ }^{3}$ and \\ Chinedu Joseph OKONKWO ${ }^{2}$
}

\author{
${ }^{1}$ National Biotechnology Development Agency, Abuja, Nigeria \\ ${ }^{2}$ Department of Biochemistry, University of Port Harcourt, Rivers state, Nigeria \\ ${ }^{3}$ Department of Pure and Industrial Chemistry, University of Port Harcourt, Rivers state, Nigeria
}

\begin{abstract}
To date, limited information exists on the distribution of endocrine disrupting compounds in groundwater resources from African rural settlements. In view of this knowledge gap, the present study investigated the concentrations and potential health risks of phenolic endocrine disrupting chemicals (EDCs) in underground water samples obtained from eight rural settlements in Nigeria, West Africa. The water samples were obtained from domestic drinkable communal wells at Anambra (Mgbaukwu and Umudioka), Lagos (Bariga, Itire and Mushin), and Delta (Agbarho, Ikweghwu and Orhokpokpor) states representing the South-East, South-West and South-South Nigeria respectively. Samples were analyzed for 10 selected chlorinated, nitrogen-containing and alkyl phenolic compounds using gas chromatography coupled with flame ionization detector technique. At all understudied sites, selected phenolic compounds with the exception of 2-chlorophenol which was below detectable limits at 4 sites (Agbarho, Mgbaukwu, Umudioka site 1 and Mushin) were detected. The concentrations of the phenolic compounds in the samples from the different sites ranged between below detectable limits to $0.0904 \mathrm{ppm}$. Nonylphenol, 2,4-dinitrophenol and 2,4,6-trichlorophenol were predominant at EDCs in most sites when compared with the other phenolic contaminants. The calculated chronic daily intake (CDI) results for the exposed populations at the communities implies that the level of occurrence and daily intake of 2-nitrophenol, 2,4-dimethylphenol, 4-nitrophenol, 2-chlorophenol and bisphenol A were still below their respective oral reference doses. Nonylphenol and 2,4,6-trichlorophenol (risk quotient, RQ > 1) were identified as the major EDC contributors to potential health risk for exposed populations at the communities.
\end{abstract}

Keywords: endocrine disrupting chemicals, phenolic compounds, water, risk assessment.

\section{Introduction}

Endocrine disrupting compounds (EDCs) have been the subject of critical research interest in the last three decades because they have been reported to interfere with the normal functioning of the endocrine system and cause a wide range of health issues from growth and developmental disorders [1], abnormalities in sex organs [2], endometriosis [3], respiratory issues to metabolic and neurological problems [4]. Most of these chemical compounds are used in the industries for the production of pesticides, cosmetics, personal care products, plastics, pharmaceuticals, etc. These chemicals have the potential of leaching into various ground waters, surface water bodies, air and soil and eventually make their way into the human endocrine system where they cause harm [5].

Phenolic compounds are among the several endocrine disrupting compound which has attracted the interest of the scientific community due to its increasing production and consumption rates. 4-nonylphenol (NP), 4-t-octylphenol (OP) and bisphenol A (BPA) are among the most frequently reported and ecotoxicologically significant EDC's in Nigeria [6 - 9]. BPA is used in epoxy resin and polycarbonate plastics in food and drink packaging [10]. OP and NP are used as precursors to produce non-ionic surfactants [11].
Currently, the pollution of the global water cycle with persistent organic contaminants remains one of the major challenges of the 21 st century. The majority of these organic substances are only partially removed by conventional wastewater treatment plants. Many of these contaminants escape into the environment and spread across different ecological compartments thus increasing the exposure risk of citizens [12, 13]. In developing countries like Nigeria, many rural communities depend on shallow groundwater sources for domestic water use. While groundwater is considered the most resilient source of drinking water across much of Africa, improper management of household and agricultural waste in rural areas is a growing concern [14]. There is very little information on studies monitoring the levels of micro-organic pollutants in African groundwater systems. Where such studies have been conducted, the focus has been on the urban areas.

Regulation of endocrine disrupting compounds is still at its infant stage in many African countries $[15,16]$. There is urgent need for consistent monitoring and strict regulatory frame work by environment protection agencies to formulate laws in order to reduce the level of environmental pollution by these organic pollutants in rural as well as urban areas. Considering the scarcity

\footnotetext{
* Corresponding author. E-mail address: chioma.okereke@uniport.edu.ng (Chioma Joy Okonkwo)
} 
of data on the occurrence and potential health risks of phenolic EDCs in shallow groundwater from Nigerian rural areas, this study aimed to monitor phenolic compounds in drinking well water samples obtained from selected rural settlements located in three Nigerian states (Delta, Lagos and Anambra) to ascertain the levels of concentration and possible health implications.

\section{Experimental}

\subsection{Description of study locations (Delta, Lagos and Anambra states)}

Three rural settlements (Agbarho, Ikweghwu and Orhokpokpor) located in Ughelli North local government area of Delta state, South-south Nigeria were selected for this study. Ughelli North is one of the oil producing locations in the state, and farming is the predominant occupation for the dwellers. Several oil spillages have been reported in this region, with the recent one which occurred in Warri North council area in 2018, which within $112 \mathrm{~km}$ away from the study area [17]. In Lagos state South-west Nigeria, Mushin, Itire and Bariga were selected as study locations. Lagos is the major hub of industrial and commercial activities in Nigeria and the largest city in West Africa. Mgbakwu and Umudioka rural settlements located in Anambra, South East Nigeria. These villages have smaller population size compared to the other study areas. Farming is the major preoccupation of the people. In all the eight communities selected (Table 1), the populace relies majorly on shallow groundwater for domestic use.

Table 1. Location of sampling sites.

\begin{tabular}{|l|l|l|l|l|}
\hline & Site & State & Latitude & Longitude \\
\hline 1 & Agbarho & Delta & $05^{\circ} 47^{\prime} \mathrm{N}$ & $05^{\circ} 52^{\prime} \mathrm{E}$ \\
\hline 2 & Ikweghwu & Delta & $05^{\circ} 34^{\prime} \mathrm{N}$ & $05^{\circ} 53^{\prime} \mathrm{E}$ \\
\hline 3 & Orhokpokpo & Delta & $05^{\circ} 36^{\prime} \mathrm{N}$ & $05^{\circ} 51^{\prime} \mathrm{E}$ \\
\hline 4 & Mushin & Lagos & $06^{\circ} 31^{\prime} \mathrm{N}$ & $03^{\circ} 21^{\prime} \mathrm{E}$ \\
\hline 5 & Itire & Lagos & $06^{\circ} 30^{\prime} \mathrm{N}$ & $03^{\circ} 19^{\prime} \mathrm{E}$ \\
\hline 6 & Bariga & Lagos & $06^{\circ} 32^{\prime} \mathrm{N}$ & $03^{\circ} 51^{\prime} \mathrm{E}$ \\
\hline 7 & Umudioka & Anambra & $06^{\circ} 13^{\prime} \mathrm{N}$ & $07^{\circ} 3^{\prime} \mathrm{E}$ \\
\hline 8 & Mgbakwu & Anambra & $06^{\circ} 16^{\prime} \mathrm{N}$ & $07^{\circ} 3^{\prime} \mathrm{E}$ \\
\hline
\end{tabular}

\subsection{Sample collection}

Between June and July 2019, a total 8 shallow groundwater samples were collected. Samples were collected from the eight selected study areas. The samples were isolated from insect repellants, pharmaceutical products, colognes and other personal care products to avoid possible incidence of contaminations. All 8 samples were collected in a precleaned glass bottle and immediately transported in a cooler box with ice chests to the laboratory for analysis.

\subsection{Materials}

Except specified all reagents used in this study are of analytical grade purchased from Sigma Aldrich, UK.

\subsection{Sample extraction, clean-up and GC-FID analysis} Liquid-liquid extraction technique was performed based on a slightly modified work [28]. $100 \mathrm{~mL}$ of each sample was measured into a separatory funnel and $2 \mathrm{~mL}$ of concentrated sulfuric acid $\left(\mathrm{H}_{2} \mathrm{SO}_{4}\right)$ was added to the measured sample.

Another $50 \mathrm{~mL}$ of acetone $\left(\mathrm{CH}_{3} \mathrm{COCH}_{3}\right)$ was added, shaken and vented for five minutes. The sample was allowed to separate into organic and aqueous layer. Then the organic layer was immediately transferred into a rotary evaporator and concentrated to $2 \mathrm{~mL}$. Activated sodium sulfate $\left(\mathrm{Na}_{2} \mathrm{SO}_{4}\right)$ was used to clean up the extract in a packed column and was concentrated to $1 \mathrm{~mL}$, and $1 \mu \mathrm{L}$ of the clean extract was injected into the Gas chromatograph - Flame Ionization Detector (GC/FID, Varian CP3800) for the separation of the phenol components in the column. Standard stock solutions of 4-nonylphenol (Sigma) and EPA 604-M phenols were prepared in methanol from pure analytical standards (Sigma-Aldrich).

The analytes were detected using the GC/FID peak identification software. The detection was enabled by identification of the appropriate retention time window for each compound in the calibration solutions. The quantification of the phenolic compounds of interest was possible from analytical calibration curves and the limits of detection for each analyte obtained according to the published procedure [8, 29]. The limits of detection $(\mathrm{g} / \mathrm{L})$ are as follows: 2-chlorophenol 0.041; 2nitrophenol $0.044 ; 2,4$-dimethylphenol $0.034 ; 2,4$ dichlorophenol 0.046; 4-chloro-3-methyl phenol 0.042; 2,4,6-trichlorophenol 0.024, 2,4-dinitrophenol 0.22, 4nitrophenol 0.18; bisphenol A 0.001; nonylphenol 0.002 .

\subsection{Chromatographic conditions}

Split less mode injection method was deployed and DB$5 \mathrm{~ms}$ capillary chromatographic columns of $30 \mathrm{~m} \times 0.25$ $\mathrm{mm}$ (inner diameter) $\times 0.25 \mu \mathrm{m}$ (film thickness) was used. The injection port temperature was maintained at $260{ }^{\circ} \mathrm{C}$, while the column temperature was initially set at $100^{\circ} \mathrm{C}$ for $3 \mathrm{~min}$, and was later increased to $270{ }^{\circ} \mathrm{C}$ at $10{ }^{\circ} \mathrm{C} / \mathrm{min}$ interval, and maintained for $2 \mathrm{~min}$; it was finally increased to $300{ }^{\circ} \mathrm{C}$ at $10^{\circ} \mathrm{C} / \mathrm{min}$ intervals and maintained for $2 \mathrm{~min}$. The detector temperature was 280 ${ }^{\circ} \mathrm{C}$. The carrier gas was hydrogen while the make-up gas was air with flow rate of $10 \mathrm{~mL} / \mathrm{min}$.

\subsection{Human health risk assessment}

For the assessment of health risks through oral ingestion of the phenolic endocrine disrupting compounds in the drinking water, the chronic daily intake (CDI) and risk quotient (RQ) for each of the phenolic EDCs were calculated using the following mathematical relationships [18]:

$$
\mathrm{CDI}=\frac{C n \times I R}{B W}
$$

where $C n(\mathrm{mg} / \mathrm{L})$ represents the concentration of each EDC in the water sample at test site; $B W$ represents the average body weight $(\mathrm{kg})$ assumed to $70 \mathrm{~kg}$ for an adult and $10 \mathrm{~kg}$ for a child; $I R$ is the drinking water ingestion rate (L/day) (assumed to be 1 and 2 for children and adults respectively);

$$
\mathrm{RQ}=\frac{C n}{D W E L}
$$

where DWEL is the Drinking Water Equivalent Level [19].

$$
\mathrm{DWEL}=\frac{(A D I \times B W \times H Q)}{(D W I \times A B \times F O E)}
$$


where $A D I$ is the acceptable daily intake $(\mathrm{mg} / \mathrm{kg} /$ day); $H Q$ is the hazard quotient, assumed to be $1 ; D W I$ indicates the drinking water intake (L/day); DWI rate of $1 \mathrm{~L} /$ day for infants and children $(<10$ years of age $)$ ad 2 $\mathrm{L} /$ day for adults $(\geq 10$ years of age) was assumed. $\mathrm{AB}$ is the gastrointestinal absorption rate, assumed to be 1 , and FOE represents the frequency of exposure (days/365 days), assumed to be 0.96 (350 days $/ 365$ days $=0.96)$ [20, 21].

An RQ value of $>1$ indicates there is a potential health risk to those exposed.

Table 2. Estimated drinking water equivalent derivatives for the selected phenolic endocrine disruptors for risk quotient evaluation in the study $[19,21]$.

\begin{tabular}{|l|l|l|l|}
\hline \multirow{2}{*}{$\begin{array}{c}\text { Phenolic } \\
\text { EDCs }\end{array}$} & \multirow{2}{*}{$\begin{array}{c}\text { Acceptable } \\
\text { daily intake } \\
\text { (mg/kg/day) }\end{array}$} & \multicolumn{2}{|c|}{$\begin{array}{c}\text { Drinking Water } \\
\text { Equivalent Level (mg/L) }\end{array}$} \\
\cline { 3 - 5 } & 0.008 & 0.292 & 0.083 \\
\hline 2-nitrophenol & 0.4 child \\
\hline $\begin{array}{l}\text { 2,4- } \\
\text { dimethylphenol }\end{array}$ & 0.02 & 0.729 & 0.208 \\
\hline $\begin{array}{l}\text { 2,4- } \\
\text { dichlorophenol }\end{array}$ & 0.003 & 0.109 & 0.031 \\
\hline $\begin{array}{l}\text { 4-chloro-3- } \\
\text { methylphenol }\end{array}$ & $\mathrm{NA}$ & $\mathrm{ID}$ & $\mathrm{ID}$ \\
\hline $\begin{array}{l}\text { 2,4,6- } \\
\text { trichlorophenol }\end{array}$ & 0.0003 & 0.011 & 0.003 \\
\hline $\begin{array}{l}\text { 2,4- } \\
\text { dinitrophenol }\end{array}$ & 0.002 & 0.073 & 0.208 \\
\hline 4-nitrophenol & 20 & 729.167 & 208.333 \\
\hline Nonylphenol & 0.0005 & 0.002 & 0.005 \\
\hline $\begin{array}{l}\text { Bisphenol A } \\
\text { (BPA) }\end{array}$ & 0.05 & 1.823 & 0.521 \\
\hline 2-chlorophenol & 0.005 & 0.182 & 0.052 \\
\hline
\end{tabular}

NA- no available data

ID- Insufficient data to derive value

\section{Results and discussion}

\subsection{Levels and distribution of phenolic EDCs in the shallow groundwater samples}

The concentrations and distribution of phenolic EDC's in the various well water samples from the eight communities in this study are presented in Tables 3 to 5. The frequency of detection was $50 \%$ for 2-chlorophenol and $100 \%$ for the other phenolic contaminants in the shallow groundwater samples. The results from Table 3 showed that the concentrations of the phenolic compounds ranged from below detectable limits to $0.0904 \mathrm{ppm}$ in the samples from the Delta study location. Nonylphenol (0.0903 ppm), 2,4,6trichlorophenol (0.0904 ppm) and 2-nitrophenol (0.0087 ppm) were the predominant EDCs in the samples from Agbarho, Ikweghwu and Orhokpokpor villages respectively. The high levels of 2-nitrophenol and 2,4,6trichlorophenol in the water source could be attributed to the agricultural activities and the usage of pesticides by the local resource farmers in this community who majorly cultivate cassava and fluted pumpkins. These pesticides leach through the soils into the ground water over time. The incessant use of pesticides for agricultural purposes has led to the increased level of organic pollution in the soil, water and air [22]. Nonylphenol has attracted attention due to its prevalence in the environment and its potential role as an endocrine disruptor and xenoestrogen, due to its ability to act with estrogen-like activity. It functions as a primary intermediate in the production of the non-ionic surfactants, nonylphenol exthoxylates used in the production of pesticides, paints and personal care products. The ground water samples investigated at some sites in the Hamdan city of western Iran revealed that nonylphenol and bisphenol A were found to be in the ranges of $0.001 \mathrm{ng} / \mathrm{L}$ to $0.9 \mathrm{ng} / \mathrm{L}$ [23]. Samples from Mgbaukwu and Umudioka (Table 4) did not yield 2chlorophenol in detectable levels. 4-nitrophenol was the highest occurring phenolic contaminant with values of $0.0774 \mathrm{ppm}$ and $0.2040 \mathrm{ppm}$ at Mgbaukwu and Umudioka respectively. 4-Nitrophenol is an intermediate in the synthesis of paracetamol. It is also used as the precursor for the preparation of phenetidine and acetophenetidine, which serve as indicators, and raw materials for fungicides [24]. Human exposure to 4nitrophenol can result to irritation of the skin, eyes and the gastrointestinal tract [25].

At the three study sites from Lagos, 2,4dinitrophenol (0.0554 ppm), 2-nitrophenol (0.0077 $\mathrm{ppm})$ and 2,4-dichlorophenol (0.0111 ppm) were the phenolic contaminants with the highest concentration in the groundwater from Mushin, Itire and Bariga sites respectively. Nonylphenol (0.0409 ppm) was the second predominant phenolic contaminant at the Mushin site. Other phenolic EDCs were at much lower concentrations in Itire and Bariga sites. Agricultural activities are almost nonexistent in the rural areas of Lagos state due to increased urbanization. So the presence of these phenolic contaminants can be attributed to the heavy industrial presence scattered all around Lagos and its environs. Some of these industries makes use of phenols and its derivatives in the production of various items. Lagos is the major commercial hub in Nigeria. Phenols are known to be released in the air via its production and use in phenolic resins and organic synthesis which eventually settle on soil surfaces and leach into underground water. A similar study [26] at some underground water sites in Aurangabad city in India revealed much lower concentrations of 4-nitrophenol, 4-chloro-3methylphenol, 2-chlorophenol, 2,4-dinitrophenol and 2,4,6-trichlorophenols and the values ranged from 3 $\mathrm{ng} / \mathrm{L}$ to $17 \mathrm{ng} / \mathrm{L}$ when compared to the present study. In the light of the present result, it is suggested that proper measures for the management of agricultural and industrial wastes be adopted to preserve the groundwater resource especially in rural areas.

Table 3. Concentrations (ppm) of selected phenolic contaminants in underground well water samples collected from Agbarho, Ikweghwu and Orhokpokpor villages in Delta state.

\begin{tabular}{lccc}
\hline \multicolumn{1}{c}{$\begin{array}{c}\text { Sample sites/ } \\
\text { Contaminants }\end{array}$} & Agbarho & Ikweghwu & Orhokpokpor \\
\hline 2-nitrophenol & 0.0257 & 0.0125 & 0.0087 \\
$\begin{array}{l}\text { 2,4-dimethylphenol } \\
\text { 2,4-dichlorophenol }\end{array}$ & 0.0258 & 0.0239 & 0.0001 \\
$\begin{array}{l}\text { 4-chloro- } \\
\text { 3-methylphenol }\end{array}$ & 0.0267 & 0.0559 & 0.0084 \\
$\begin{array}{l}\text { 2,4,6- } \\
\text { trichlorophenol }\end{array}$ & 0.0194 & 0.0904 & 0.0000 \\
$\begin{array}{l}\text { 2,4-dinitrophenol } \\
\text { 4-nitrophenol }\end{array}$ & 0.0870 & 0.0231 & 0.0002 \\
Nonylphenol & 0.0185 & 0.0224 & 0.0002 \\
\hline
\end{tabular}




\begin{tabular}{lccc}
\hline $\begin{array}{c}\text { Sample sites/ } \\
\text { Contaminants }\end{array}$ & Agbarho & Ikweghwu & Orhokpokpor \\
\hline Bisphenol A (BPA) & 0.0810 & 0.0032 & 0.0027 \\
2-chlorophenol & BDL & 0.0046 & 0.0009 \\
\hline$B D L=$ below detectable limit. & &
\end{tabular}

Table 4. Concentrations (ppm) of phenolic contaminants in underground well water samples collected from Mgbaukwu, and Umdioka villages in Anambra state.

\begin{tabular}{lcc}
\hline \multicolumn{1}{c}{$\begin{array}{c}\text { Sample sites/ } \\
\text { Contaminants }\end{array}$} & Mgbaukwu & Umudioka \\
\hline 2-nitrophenol & 0.0111 & 0.0106 \\
2,4-dimethylphenol & 0.0248 & 0.0130 \\
2,4-dichlorophenol & 0.0205 & 0.0189 \\
4-chloro-3-methylphenol & 0.0231 & 0.0265 \\
2,4,6-trichlorophenol & 0.0739 & 0.0493 \\
2,4-dinitrophenol & 0.0509 & 0.0478 \\
4-nitrophenol & 0.0774 & 0.2040 \\
Nonylphenol & 0.0570 & 0.0037 \\
Bisphenol A (BPA) & 0.0122 & 0.0118 \\
2-chlorophenol & $\mathrm{BDL}$ & $\mathrm{BDL}$ \\
\hline
\end{tabular}

$B D L=$ below detectable limit

Table 5. Concentrations (ppm) of phenolic contaminants in underground well water samples collected from Mushin, Itire and Bariga villages in Lagos state.

\begin{tabular}{lccc}
\hline \multicolumn{1}{c}{$\begin{array}{c}\text { Sample Sites/ } \\
\text { Contaminants }\end{array}$} & Mushin & Itire & Bariga \\
\hline 2-nitrophenol & 0.0188 & 0.0077 & 0.0003 \\
2,4-dimethylphenol & 0.0248 & 0.0004 & 0.0001 \\
2,4-dichlorophenol & 0.0201 & 0.0056 & 0.0111 \\
4-chloro-3-methylphenol & 0.0222 & 0.0012 & 0.0001 \\
2,4,6-trichlorophenol & 0.0336 & 0.0003 & 0.0001 \\
2,4-dinitrophenol & 0.0554 & 0.0072 & 0.0042 \\
\hline
\end{tabular}

\begin{tabular}{llrc}
\hline \multicolumn{1}{c}{$\begin{array}{c}\text { Sample Sites/ } \\
\text { Contaminants }\end{array}$} & \multicolumn{1}{c}{ Mushin } & Itire & Bariga \\
\hline 4-nitrophenol & 0.0360 & 0.0006 & 0.0002 \\
Nonylphenol & 0.0409 & 0.0001 & 0.0002 \\
Bisphenol A (BPA) & 0.0084 & 0.0018 & 0.0004 \\
2-chlorophenol & BDL & 0.0012 & 0.0019 \\
\hline
\end{tabular}

$B D L=$ below detectable limit

\subsection{Human Health risk assessment of the phenolic EDCs}

Tables 6-8 show the CDI via oral exposure for children and adult populations of the eight selected communities in the study. The calculated CDI results for the exposed populations at the communities implies that the level of occurrence and daily intake of 2-nitrophenol, 2,4dimethylphenol, 4-nitrophenol, 2-chlorophenol and bisphenol A were still below their respective oral reference doses [21]. CDI values ranged from BDL to 0.02040 and BDL to $0.00258 \mathrm{mg} / \mathrm{kg} /$ day for children and adult populations respectively. For the adult population, nonylphenol (0.00258), 2,4,6trichlorophenol (0.00258), 2-nitrophenol (0.00025), 4nitrophenol (0.00221), 2,4-dinitrophenol (0.00158), 4nitrophenol (0.00538), 2-nitrophenol (0.00022), 2,4dichlorophenol (0.00032) had the highest CDI among the selected phenolic contaminants in the groundwater from Agbarho, Ikweghe, Orhokpokpo, Mgbaukwu, Mushin, Umudioka, Itire and Bariga communities respectively. Higher CDI values were observed for children. This is a future health concern as children have longer exposure duration [18].

Table 6. Chronic daily intake (CDI) for Agbarho, Ikweghe and Orhokpokpo communities.

\begin{tabular}{lcccccc}
\hline \multicolumn{1}{c}{ Phenolic EDCs } & \multicolumn{2}{c}{ Agbarho } & \multicolumn{2}{c}{ Ikweghe } & \multicolumn{2}{c}{ Orhokpokpor } \\
& child & adult & child & adult & child & adult \\
\hline 2-nitrophenol & 0.00257 & 0.00073 & 0.00125 & 0.00036 & 0.00870 & 0.00025 \\
2,4-dimethylphenol & 0.00258 & 0.00074 & 0.00239 & 0.00068 & 0.00001 & 0.00000 \\
2,4-dichlorophenol & 0.00251 & 0.00072 & 0.00492 & 0.00141 & 0.00084 & 0.00024 \\
4-chloro-3-methylphenol & 0.00267 & 0.00076 & 0.00559 & 0.00160 & 0.00001 & 0.00001 \\
2,4,6-trichlorophenol & 0.00194 & 0.00055 & 0.00904 & 0.00258 & 0.00002 & 0.00001 \\
2,4-dinitrophenol & 0.00870 & 0.00249 & 0.00231 & 0.00066 & 0.00037 & 0.00012 \\
4-nitrophenol & 0.00185 & 0.00053 & 0.00224 & 0.00064 & 0.00002 & 0.00001 \\
Nonylphenol & 0.00903 & 0.00258 & 0.00213 & 0.00061 & 0.00001 & 0.00001 \\
Bisphenol A & 0.00810 & 0.00231 & 0.00032 & 0.00009 & 0.00027 & 0.00008 \\
2-chlorophenol & BDL & BDL & 0.00046 & 0.00013 & 0.00009 & 0.00003 \\
\hline
\end{tabular}

Table 7. Chronic daily intake (CDI) for Mgbaukwu and Umudioka communities.

\begin{tabular}{lcccc}
\hline \multirow{2}{*}{ Phenolic EDCs } & \multicolumn{2}{c}{ Mgbakwu } & \multicolumn{2}{c}{ Umudioka } \\
& child & adult & child & adult \\
\hline 2-nitrophenol & 0.00111 & 0.00032 & 0.00106 & 0.00030 \\
2,4-dimethylphenol & 0.00248 & 0.00071 & 0.00130 & 0.00037 \\
2,4-dichlorophenol & 0.00205 & 0.00059 & 0.00189 & 0.00054 \\
4-chloro-3- & 0.00231 & 0.00066 & 0.00265 & 0.00076 \\
methylphenol & & 0.00211 & 0.00493 & 0.00141 \\
2,4,6-trichlorophenol & 0.00739 & 0.00145 & 0.00479 & 0.00137 \\
2,4-dinitrophenol & 0.00509 & 0.00221 & 0.02040 & 0.00583 \\
4-nitrophenol & 0.00774 & 0.00011 \\
Nonylphenol & 0.00570 & 0.00163 & 0.00037 & 0.00011 \\
Bisphenol A & 0.00122 & 0.00035 & 0.00118 & 0.00034 \\
2-chlorophenol & $\mathrm{BDL}$ & $\mathrm{BDL}$ & $\mathrm{BDL}$ & $\mathrm{BDL}$ \\
\hline
\end{tabular}

Table 8. Chronic daily intake (CDI) for Mushin, Itire and Bariga communities.

\begin{tabular}{lccccccc}
\hline \multicolumn{1}{c}{ Phenolic EDCs } & \multicolumn{2}{c}{ Mushin } & \multicolumn{2}{c}{ Itire } & \multicolumn{2}{c}{ Bariga } & \multicolumn{2}{c}{ child } & adult \\
\hline 2-nitrophenol & child & adult & child & adult & 0.00001 \\
2,4-dinitrophenol & 0.00188 & 0.00054 & 0.00077 & 0.00022 & 0.0003 & 0.0001 \\
2,4-dichlorophenol & 0.00248 & 0.00071 & 0.00004 & 0.00001 & 0.00001 & 0.00001 \\
\hline
\end{tabular}




\begin{tabular}{lcccccc}
\hline \multicolumn{1}{c}{ Phenolic EDCs } & \multicolumn{2}{c}{ Mushin } & \multicolumn{2}{c}{ Itire } & \multicolumn{2}{c}{ Bariga } \\
& child & adult & child & adult & child & adult \\
\hline 4-chloro-3-methylphenol & 0.00222 & 0.00063 & 0.00012 & 0.00003 & 0.00001 & 0.00001 \\
2,4,6-trichlorophenol & 0.00336 & 0.00096 & 0.00003 & 0.00001 & 0.00001 & 0.00001 \\
2,4-dinitrophenol & 0.00554 & 0.00158 & 0.00072 & 0.00021 & 0.00042 & 0.00012 \\
4-nitrophenol & 0.00360 & 0.00103 & 0.00006 & 0.00002 & 0.00002 & 0.00001 \\
Nonylphenol & 0.00409 & 0.00117 & 0.00001 & 0.000003 & 0.00002 & 0.00010 \\
Bisphenol A & 0.00084 & 0.00024 & 0.00018 & 0.00005 & 0.00004 & 0.00001 \\
2-chlorophenol & BDL & BDL & 0.00012 & 0.00003 & 0.00019 & 0.00005 \\
\hline
\end{tabular}

Table 9. Risk quotient for Agbarho, Ikweghwu and Orhokpokpor communities

\begin{tabular}{|c|c|c|c|c|c|c|}
\hline \multirow{2}{*}{ Phenolic EDCs } & \multicolumn{2}{|c|}{ Agbarho } & \multicolumn{2}{|c|}{ Ikweghwu } & \multicolumn{2}{|c|}{ Orhokpokpor } \\
\hline & adult & child & adult & child & adult & child \\
\hline 2-nitrophenol & 0.0880 & 0.3096 & 0.0428 & 0.1506 & 0.0298 & 0.1048 \\
\hline 2,4-dimethylphenol & 0.0354 & 0.1240 & 0.0328 & 0.1149 & 0.0001 & 0.0005 \\
\hline 2,4-dichlorophenol & 0.2303 & 0.8097 & 0.4514 & 1.5871 & 0.0771 & 0.2709 \\
\hline 4-chloro-3-methylphenol & N/A & N/A & N/A & N/A & N/.A & N/A \\
\hline 2,4,6-trichlorophenol & 1.7636 & 6.4667 & 8.2100 & 30.1333 & 0.0182 & 0.0667 \\
\hline 2,4-dinitrophenol & 1.1912 & 0.3164 & 1.7769 & 0.1111 & 0.0507 & 0.0178 \\
\hline 4-nitrophenol & 0.0000 & 0.0000 & 0.0000 & 0.0001 & 0.0001 & 0.0000 \\
\hline Nonylphenol & 45.1500 & 18.0600 & 10.6500 & 4.2600 & 0.0500 & 0.0200 \\
\hline Bisphenol A & 0.0444 & 0.1555 & 0.0018 & 0.0061 & 0.0015 & 0.0052 \\
\hline 2-chlorophenol & BDL & BDL & 0.0253 & 0.0885 & 0.0049 & 0.0173 \\
\hline
\end{tabular}

Table 10. Risk quotient for Mgbaukwu and Umudioka sites.

\begin{tabular}{llccc}
\hline \multicolumn{1}{c}{ Phenolic EDCs } & \multicolumn{2}{c}{ Mgbaukwu } & \multicolumn{2}{c}{ Umudioka } \\
& \multicolumn{1}{c}{ adult } & child & adult & child \\
\hline 2-nitrophenol & 0.0380 & 0.1337 & 0.0363 & 0.1277 \\
2,4-dimethylphenol & 0.0340 & 0.1192 & 0.0178 & 0.0625 \\
2,4-dichlorophenol & 0.1881 & 0.66513 & 0.1734 & 0.6097 \\
4-chloro-3-methylphenol & $\mathrm{N} / \mathrm{A}$ & $\mathrm{N} / \mathrm{A}$ & $\mathrm{N} / \mathrm{A}$ & $\mathrm{N} / \mathrm{A}$ \\
2,4,6-trichlorophenol & 6.7182 & 24.6333 & 4.4818 & 16.4333 \\
2,4-dinitrophenol & 0.6973 & 0.2447 & 0.6548 & 0.2298 \\
4-nitrophenol & 0.0001 & 0.0004 & 0.0003 & 0.0009 \\
Nonylphenol & 28.5000 & 11.4000 & 1.8500 & 0.7400 \\
Bisphenol A & 0.0067 & 0.0234 & .0065 & 0.0234 \\
2-chlorophenol & $\mathrm{BDL}$ & $\mathrm{BDL}$ & $\mathrm{BDL}$ & $\mathrm{BDL}$ \\
\hline
\end{tabular}

Table 11. Risk quotient for Mushin, Itire and Bariga communities.

\begin{tabular}{|c|c|c|c|c|c|c|}
\hline \multirow{2}{*}{ Phenolic EDCs } & \multicolumn{2}{|c|}{ Mushin } & \multicolumn{2}{|c|}{ Itire } & \multicolumn{2}{|c|}{ Bariga } \\
\hline & adult & child & adult & child & adult & child \\
\hline 2-nitrophenol & 0.0644 & 0.2265 & 0.02645 & 0.0928 & 0.0010 & 0.0036 \\
\hline 2,4-dimethylphenol & 0.0340 & 0.1192 & 0.0005 & 0.0019 & 0 & 0 \\
\hline 2,4-dichlorophenol & 0.1844 & 0.6484 & 0.0514 & 0.1806 & 0.1018 & 0.3581 \\
\hline 4-chloro-3-methylphenol & N/A & N/A & N/A & N/A & N/A & N/A \\
\hline 2,4,6-trichlorophenol & 3.0545 & 11.2000 & 0.0272 & 0.1000 & 0 & 0 \\
\hline 2,4-dinitrophenol & 0.7589 & 0.2663 & 0.0986 & 0.0346 & 0.0575 & 0.0202 \\
\hline 4-nitrophenol & 0.0000 & 0.0002 & 0.0000 & 0.0000 & 0.0000 & 0.0000 \\
\hline Nonylphenol & 20.4500 & 8.1800 & 0.0200 & 0.0200 & 0.1000 & 0.0400 \\
\hline Bisphenol A & 0.0046 & 0.0161 & 0.0009 & 0.0002 & 0.0002 & 0.0008 \\
\hline 2-chlorophenol & BDL & BDL & 0.0231 & 0.0104 & 0.0104 & 0.0365 \\
\hline
\end{tabular}

The results for the calculated risk quotients for the children and adult populations at the communities in the study are presented in Tables 9-11. It was observed that at the Agbarho, Ikweghe, Mgbaukwu, Umudioka and Mushin sites, the children and adult population may be at potential risk of nonylphenol and 2,4,6trichlorophenol related toxicity. The risk quotient values for both phenolic contaminants were greater than 1 in all cases. This indicates that drinking the raw groundwater from these sites without any form of treatment is unsafe. The risk quotient for the children was higher for children at all eight communities. This is similar to other reported results [27] that in early life stage (infants and children, birth to $<12$ months and 1 to $<11$ years of age, respectively) RQs could be approximately 6 times greater than the RQs for adulthood ( $\geq 21$ years of age). The present results thus indicate that nonylphenol and 2,4,6-trichlorophenol are the major EDC contributors to potential health risk for exposed populations at the communities.

\section{Conclusions}

This study has shown the groundwater quality in the selected rural areas was seriously threatened by the presence of significant concentrations of phenolic EDCs. Although CDI for some of the phenolic EDCs (2nitrophenol, 2,4-dimethylphenol, 4-nitrophenol, 2chlorophenol and bisphenol A) at the communities fell below the USEPA oral reference dose, the RQs for nonylphenol and 2,4,6-trichlorophenol were above 1 for the exposed children and adult populations. This result raises serious concern over the status of EDC pollution in Nigerian groundwater resource. Thus, there is need for strict environment regulations by various health and environment agencies on the production and use of phenolic compounds and also to continuously monitor 
the levels of phenolic chemicals in the underground water as long term exposure may cause serious health hazards.

\section{Conflict of interest}

The authors declare that there is no conflict of interest.

\section{References}

[1]. K.E. Pelch, J.M. Beeman, B.A. Niebruegge, S.R. Winkeler, S.C. Nagel, Endocrine-disrupting chemicals (EDCs) in mammals. In: Hormones and Reproduction of Vertebrates; Elsevier, Amsterdam 2011, pp. 329-371.

[2]. H.B. Patisaul, Endocrine Disruption of Vasopressin Systems and Related Behaviors, Front. Endocrinol. (Lausanne) 19 (2017) 134.

[3]. H. Gao, B. Yang, N. Li, L. Feng, X. Shi, W. Zhao, S. Liu, Bisphenol A and hormone-associated cancers: current progress and perspectives, Medicine (Baltimore) 94 (2005) e211.

[4]. M. Czerska, M. Zieliski, J. Kamiska, D. Ligocka, Effect of polybrominated diphenyl ethers on thyroid hormone, neurodevelopment and fertility in rodents and humans, Int. J. Occup. Med. Environ. Health 26 (2013) 498-510.

[5]. T.T. Schug, A.F. Johnson, L.S. Birnbaum, T. Colborn, L.J. Guillette, D.P. Crews, T. Collins, A.M. Soto, F.S. Vom-Saal, J.A. McLachlan, C. Sonnenschein, J.J Heindel, Minireview: Endocrine disruptors, past lessons and future directions, Mol. Endocrin. 30 (2016) 833-84.

[6]. A. Arukwe, T. Eggen, M. Moder, Solid waste deposits as a significant source of contaminants of emerging concern to the aquatic and terrestrial environments - a developing country case study from Owerri, Nigeria, Sci. Total Environ. 438 (2012) 94-102.

[7]. A.A. Oketola, T.K. Fagbemigun, Determination of nonylphenol, octylphenol and bisphenol-A in water and sediments of two major river Lagos, Nigeria, J. Environ. Prot. 4 (2013) 38-45.

[8]. E.J. Inam, N. Offiong, S. Kang, P. Yang, J. Essien, Assessment of the occurrence and risks of emerging organic pollutants (EOPs) in Ikpa River Basin freshwater ecosystem, Niger Delta-Nigeria, Bull. Environ. Contam. Toxicol. 95 (2015) 624631.

[9]. E.J. Inam, I.M. Nwoke, E.D. Udosen, N. Offiong, Ecological risks of phenolic endocrine disrupting compounds in an urban tropical river, Environ. Sci. Poll. Res. 26 (2019) 21589-21597.

[10]. J.A. Rogers, L. Metz, Y.V. Wee, Review: endocrine disrupting chemicals and immune responses: a focus on bisphenol-A and its potential mechanisms, Mol. Immunol. 53 (2013) 421-430.

[11]. Y. Jie, Y. Jin, L. Ya, M. Yang, L. Wenmei, Y. Yu, H. Liting, X. Jie, The adverse effects of chronic low dose exposure to nonylphenol on type 2 diabetes mellitus in high sucrose-high fat diet treated rats, Islets 10 (2018) 1-9.
[12]. M.J. Focazio, D.W. Kolpin, K.K. Barnes, E.T. Furlong, M.T. Meyer, S.D. Zaugg, L.B. Barber, M.E. Thurman, A national reconnaissance for pharmaceuticals and other organic wastewater contaminants in the United States-II) untreated drinking water sources, Sci. Total Environ. 402 (2008) 201-216.

[13]. S.W. Nam, B.I. Jo, Y. Yoon, K.D. Zoh, Occurrence and removal of selected micropollutants in a water treatment plant, Chem. 95 (2014) 156-165.

[14]. F. Wang, J. Huisman, C.E. Meskers, M. Schluep, A. Stevels, C. Hagelüken, The best-of-2-worlds philosophy: developing local dismantling and global infrastructure network for sustainable ewaste treatment in emerging economies, Waste Manag. 32 (2012) 2134-2146.

[15]. N. Milic, M. Milanovic, N.J. Letic, M.T. Sekulic, J. Radonic, I. Mihajlovic, M.V. Miloradov, Occurrence of antibiotics as emerging contaminant substances in aquatic environment, Int. J. Environ. Health Res. 23 (2013) 296-310.

[16]. M. Gavrilescu, K. Demnerova, J. Aamand, S. Agathos, F. Fava, Emerging pollutants in the environment: present and future challenges in biomonitoring, ecological risks and bioremediation. New Biotechnol. 32 (2015) $147-$ 156.

[17]. C. Enegide, C. Chukwuma, Oil spillage and heavy metals toxicity risk in the Niger Delta, Nigeria. J. Health Poll. 8 (2018) 180905.

[18]. C.J. Okereke, E.B. Essien, M.O. Wegwu, Human health risk assessment of heavy metal contamination for population via consumption of selected vegetables and tubers grown in farmlands in Rivers State, South-South Nigeria, J. Anal. Pharm. Res. 3 (2016) 00077.

[19]. S.Y. Wee, A.Z. Aris, Endocrine disrupting compounds in drinking water supply system and human health risk implication, Environ. Intern. 106 (2017) 1-27.

[20]. US EPA Methodology for Deriving Ambient Water Quality Criteria for the Protection of Human Health. United States Environmental Protection Agency, Washington, DC (2000) (EPA-822-B-00-004).

[21]. United States Environmental Protection Agency, USEPA. 2018 Edition of the Drinking Water Standards and Health Advisories Tables Office of Water, US Environmental Protection Agency, Washington DC. (2018) (EPA 822-F-18-001).

[22]. B. Husk, J.B. Sanchez, L. Takser, O. Savary, H. Cabana, Pharmaceuticals and pesticides in rural community drinking waters of Quebec, Canada - a regional study on the susceptibility to source contamination, Water Qual. Res. J. 54 (2019) 88103.

[23]. A.J. Jafari, R.P. Abasabad, A. Salehzadeh, Endocrine disrupting contaminants in water resources and sewages in Hamadan city of Iran. Iran J. Environ. Health Sci. Eng. 6 (2009) 89-96.

[24]. F. Ellis, Paracetamol: a curriculum resource, Royal Society of Chemistry, London (2002). 
[25]. ATSDR (Agency for toxic substances and Disease Registry). Toxicological profile for Nitrophenols. Public health and human services Atlanta C.A. (1990).

[26]. Z.J. Musa, N.N. Bandela, B. Aditi, Evaluation of phenolic compounds in ground water of Aurangabad city, Ind. St. Res. J. 5 (2015) 1-5.

[27]. H.W. Leung, L. Jin, S. Wei, M.M.P. Tsui, B. Zhou, L. Jiao, P.C. Cheung, Y.K. Chun, T. Manning, Endocrine-disrupting Chemicals. A review of the State of the Science, Australasian J. Ecotoxicol. 11 (2005) 1-52.

[28]. H.G. Mol, S. Sunarto, O.M. Steijger, Determination of endocrine disruptors in water after derivatization with N-methyl-N-(tert.butyldimethyltrifluoroacetamide) using gas chromatography with mass spectrometric detection, J. Chromat. A 879 (2000) 97-112.

[29]. USEPA, Method 528 Determination of phenols in drinking water by solid phase extraction and capillary column gas chromatography/mass spectrometry (GC/MS). National Exposure Research Laboratory, Office of Research and Environment. United States Environment Protection Agency Ohio (2000) 45268.

Received: 28.08 .2019 Received in revised form: 10.11.2019 Accepted: 12.11.2019 